\title{
REAVI
}

\section{SHOPPING EXPERIENCES OF ELDERLY CONSUMERS IN SUPERMARKETS}

\section{AS EXPERIÊNCIAS DOS CONSUMIDORES DA TERCEIRA IDADE NAS COMPRAS EM SUPERMERCADOS}

Dario de Oliveira Lima-Filho*

Filipe Quevedo-Silva**

Marcos José de Almeida Matias***

\begin{abstract}
The objective of this study is to analyze the infrastructure, services and products offered by supermarkets to satisfy elderly consumers expectations. We conducted a quantitative-descriptive study with a sample of 100 people aged over 60 years, of both sexes. The sampling technique used was not a convenience probabilistic - it was performed in three supermarkets in Campo Grande, Mato Grosso do Sul, Brazil. The data was analysed by exploratory factor analysis and cluster analysis. The results show that the three supermarkets partially meet consumer expectations. Three market segments was identified. Segment 1 comprises $26 \%$ of the sample. In this group, the percentage of women was around $73 \%$, the largest share receiving a minimum salary. This group proved to be more satisfied than others. Segment 2 is made up of $44 \%$ of respondents. Segment 3 is made up of $30 \%$ of respondents. In this segment, $76 \%$ of respondents are women. This group is the most dissatisfied. Besides this results, it is necessary for managers to further investigate this group of consumers in order to better understand their wants and needs.
\end{abstract} Keywords: Consumer behavior. Market segmentation. Elderly consumer

\section{RESUMO}

O objetivo deste estudo é analisar se a infraestrutura, os serviços e os produtos oferecidos pelos supermercados satisfazem as expectativas dos consumidores da terceira idade. Foi feito um estudo quantitativo-descritivo junto a uma amostra de 100 pessoas com idade superior a 60 anos, de ambos os sexos, sendo que a técnica de amostragem utilizada foi não probabilística por conveniência, em três supermercados de Campo Grande - MS. Os dados foram anaçisados por meio de análise fatorial exploratória e análise de agrupamentos. Os resultados demonstram que os três supermercados atendem parcialmente as expectativas dos consumidores. Foram identificados três segmentos de mercado. O segmento 1 é composto por $26 \%$ da amostra. Neste grupo, o percentual de mulheres ficou em torno de $73 \%$, a maior parcela recebe um salário mínimo. Este grupo demonstrou estar mais satisfeito que os demais. $\mathrm{O}$ segmento 2 é composto por $44 \%$ dos entrevistados. O segmento 3 é formado por $30 \%$ dos respondentes. Neste segmento $76 \%$ dos entrevistados são mulheres. Este grupo é o mais insatisfeito. Apesar desses resultados, faz-se necessário, por parte do varejo, um aprofundamento dos estudos do comportamento do consumidor, para assim atender satisfatoriamente todas as expectativas dos consumidores da terceira idade.

\footnotetext{
* Universidade Federal de Mato Grosso do Sul E-mail: dariolimafilho@gmail.com

** Universidade Federal de Mato Grosso do Sul E-mail: filquevedo@ gmail.com

*** Universidade Estadual do Tocantins E-mail: marcosjmatias@ gmail.com
} 


\section{REAVI}

Palavras-chave: Comportamento do consumidor. Segmentação de mercado. Terceira Idade.

Data de submissão: 24 de abril de 2020 .

Data de aprovação: 09 de junho de 2020.

Disponibilidade: http://www.revistas.udesc.br/index.php/reavi/index

\section{INTRODUCTION}

The Brazilian Institute of Geography and Statistics (IBGE) highlights through the social and demographic indicators, reported annually, that the age structure of Brazil is changing and that the elderly group is, currently, a significant part of the population in absolute terms and in terms of increasing relative importance in the Brazilian society as a whole.

According to the Statute of the Elderly (2003), the individual over 60 years old is classified as elderly or "old age". And according to the 2010 Census (IBGE, 2010), the pace of growth of the elderly population has been systematic and consistent. The National Household Sample Survey - PNAD 2009, Brazil had a population of about 21 million people aged 60 or over. With a fertility rate below the population replacement level, combined with other factors, such as advances in health, the elderly group currently occupies a significant space in Brazilian society. In the period from 1999 to 2009 , the relative weight of the elderly (60 years of age or older) in the population as a whole went from $9.1 \%$ to $11.3 \%$.

With the increase in income and the proliferation of new consumer needs, it has become an advantageous market for retailers, recognizing that they are not facing a homogeneous mass of expectations, but with a diverse mix of submarkets (QUEVEDO-SILVA; LIMA-FILHO; FAGUNDES, 2018). Each of these submarkets or segments can be defined by common demographic, behavioral and / or psychographic characteristics. A review of the marketing literature shows a continuing interest in segmentation and sub-segmentation that still has a strong influence on Smith's 1956 approach.

Currently, analyzing market segmentation is indispensable for any organization (AHANI et al., 2019). After the 1990s, it was noted that consumer attitudes were mainly modified by competition. We are faced with more demanding customers and aware of their rights, as well as remaining on the search for lower prices and better quality products that meet their needs (FURUTA; BARRIZZELLI, 2002).

In this sense, this article proposes to analyze whether the infrastructure, services and products offered by supermarkets in Campo Grande - MS satisfy the expectations of elderly consumers. And to achieve this purpose, we sought to: (a) Describe the purchase profile of the elderly consumer in Campo Grande (MS); (b) Identify whether the supermarket infrastructure is suitable for the elderly consumer; (c) Measure whether the services offered by supermarkets, in Campo Grande (MS), are successful in assisting the elderly consumer; (d) Describe whether the products offered in supermarkets in Campo Grande (MS) meet the needs of the elderly consumer. 


\section{CONSUMER BEHAVIOR}

The study of consumer behavior and more specifically the process of adopting new products is an important advance for the theoretical basis of the marketing discipline.

Consumers are at the center of companies' attentions, and the very definition of marketing emphasizes the process of exchanges between people (MOWEN; MINOR, 2003). In the consumer behavior model, there is a chain of attitudes and related stimuli in the customer's buying process. It is noted that this process starts with the external stimuli generated by retailers, then there are the environmental stimuli, ending with the purchase process.

The aspects related to the act of consumption are diverse and increasingly relevant. That is why it is important for companies to know consumer behavior, which is influenced by four types of factors, namely: cultural, social, personal and psychological. And a search for these four factors can provide information to better reach and serve customers in an effective way (KOTLER; KELLER, 2006).

In order to understand this behavior, it is necessary to group consumers into homogeneous consumption segments, as habits and behaviors are produced and reproduced by the cultures of societies and organizations (KOTLER, 1998).

The concept of Parente (2000) comes close to the concept of Kotler (1998), in which the author designates three variables that influence the consumer when choosing how much to make available for purchases and when choosing the store to use. Therefore, the environmental variables are the retail mix and the retail mix of the competition. Environmental variables include uncontrollable forces, which must be considered in the company's management, such as: technological advances, socio-cultural aspects, demographic variables, political-legal aspects, among others.

The retail mix, or the variables that make up the marketing effort, is directly related to the controllable factors that retailers have to articulate their strategies and win consumer preference. Composing this relationship, we have: presentation, product, price, promotion and place (PARENTE, 2000). However, before planning these variables, in order to attract the consumer, it is necessary to study the profile, as well as the value and the cost / benefit ratio for its customers.

In this sense Blackwell, Miniard and Engel (2002), state that the variables that shape consumer behavior can be classified into three classes: personal characteristics, environmental influences and psychological processes. Personal characteristics, according to the same authors, can be divided between consumer resources, lifestyle, attitudes, knowledge, motivation, values. Environmental influences, on the other hand, are guided by culture, social class, family and situations in which consumers are inserted. While the category of psychological processes is related to information processing, learning and behavior change.

For the same authors, in a market segment there is a group of consumers with similar needs and behaviors, and the need to segment the market is precisely the result of differences between people. Therefore, it is important to highlight the four consumer models that, in the view of Kanuk and Schiffman (2000), are focused on an overview of how and why people behave in a certain way.

The first model is the economic model, which portrays a model of perfect competition, in which the consumer has often been characterized by making rational decisions. The second model, the passive view, is contrary to the first and describes the consumer as basically 


\section{REAVI}

submissive to the promotional efforts of marketers, since, under this view, buyers are impulsive and irrational (KANUK; SCHIFFMAN, 2000).

The third model is the cognitive one in which the consumer is seen as a problem solver, looking for products and services that meet his needs. The fourth model presents an emotional view, whereby the person tends to associate emotions with certain purchases (KANUK; SCHIFFMAN, 2000).

Smith's 1956 approach retains its value today, driving developments in the theory and practice of marketing and, in particular, techniques for market partitioning and validation of the identified homogeneous groups. According to Smith (1956), who was inspired by the economic theory of perfect competition, market segmentation as a look at the heterogeneous market as a set of homogeneous markets in response to different preferences in the various market segments. It is attributed to the wishes of consumers and users for a more precise satisfaction of their differentiated needs.

According to Richers and Lima (1991) segmentation is a subdivision of the global market into potential parts, with similar needs and desires in order to formulate marketing strategies.

The choice of segments effectively, combined with the assessment of the elements of the environment in which the company engages its activities, must be preceded by certain fundamental characteristics. It also points out that there are some innovative and important contributions that must be observed: measurability, substantiality, accessibility and operability (KOTLER, 1998).

According to the same author, some researchers try to form segments by analyzing the characteristics of the consumer, while others examine their responses, this to verify the segmentation variables, which can be used alone or in combination. Geographic segmentation dividing a market into geographic areas, with distinct units, such as: regions, cities, neighborhoods or even households. Since companies can operate in one or some geographic areas and can even divide into smaller areas. In demographic segmentation, we find variables such as: age, sex, race, income, and family life cycle, the most common of which are to distinguish consumer groups and can be associated with consumer preferences.

Psychographic segmentation is based on the lifestyle, personality, attitudes of the buyer. Behavioral segmentation are groups based on their knowledge, attitudes, use or response to a product. In multi-attribute segmentation, several variables are crossed, in an effort to identify smaller and more defined groups (MOWEN; MINOR, 2003).

According to Richers and Lima (1991), the company must focus its segmentation options from four different angles: that of products, which is a problem of adaptation; that of the segments, which is a problem of opportunity; that of the sector, which is a competition problem; distribution and communication, which is a problem of choice.

The environment of a retail store can cause impressions and influence the consumer, even if he is not aware of aromas, music and colors used to provoke different sensations and reactions. A study by Edwards and Gustafsson (2008) suggests that the atmosphere of food service stores [restaurants, cafeterias], which includes smell, can alter the length of stay, habits and satisfaction generated by the consumer, corroborating the importance of the environment in the consumer behavior.

There are several ways to classify food retail, the main ones being in the literature, primarily due to their pertinent characteristics: sales area, billing, average number of items 
available, percentage of sales of non-food products, number of check- outs and sections (SPROESSER; LIMA-FILHO, 2007; CABRINI, 2014).

A possible classification is in hypermarkets, supermarkets and convenience stores. Hypermarkets are characterized by a combination of a supermarket store and a variety store, they also offer a wide variety of non-food items, however, one to two thirds of the product mix being food products (CCRRCA, 2007).

Supermarkets are characterized by offering a complete line of grocery and meat products, predominantly selling fresh food or groceries, and hygiene and cleaning articles, also having a high turnover and low margin, working with competitive prices (CCRRCA, 2007 ; CABRINI, 2014).

Convenience stores, on the other hand, are small self-service stores, which are generally easily accessible, have more comprehensive opening hours, have a limited variety of goods and charge prices, on average, above the average observed in supermarkets (CCRRCA, 2007 CABRINI, 2014).

In this context, CCRRCA (2007) specifically for supermarkets, consumers see as positive points: Confidence; variety; high quality; fixed prices; convenience of location, time, effort and assortment; and as negative points: Limited assortment and product line; high prices compared to hypermarkets

\section{1 ELDERLY CONSUMER}

According to Debert (1999), currently, contrary to previous thoughts, old age is no longer a symbol of poverty, sadness and disease, but a privileged time for activities free from the constraints of the professional and family world. It is actually being recognized as the age of freedom, old age has been the best age, with which the human being only has to enjoy the good things in life, free from social obligations.

For Bissioli (2012), 77\% of the elderly spend between R \$ 100 and R \$ 500 per month in supermarkets; $80 \%$ have some kind of income; $20 \%$ associate shopping as a leisure activity and $70 \%$ think before finalizing a purchase in addition to not shopping on weekends.

According to André et al. (2017), the elderly consumers have particular eating habits. Has been notice a change in the age distribution of the countries. There has been a increase of the elderly population. For the World Health Organization (2008) it is estimated that in the next 15 years Brazil will be the sixth country in the world with the largest number of elderly people. This shows that the country is aging and entrepreneurs need to innovate and open new spaces that value these people.

In the case of the elderly population, there are also specific factors that can affect food consumption: socioeconomic, psychosocial, physiological and physical. Socioeconomic factors have a great influence on food consumption among the elderly, both in quantity and quality. Some studies (QUEVEDO-SILVA; LIMA-FILHO; FAGUNDES, 2018) have pointed out that the quality of life and health of the elderly consumers is related with their economic status. In addition, the percentage of elderly people who consume less than 1000 calories daily is higher among people with less purchasing power; consequently, lower expenses with frequent food are associated with a decrease or malnutrition.

Among the physiological factors, it is noted that during aging or the human body undergoes several changes and these changes affect the nutritional and the food consumption

Revista Eletrônica do Alto Vale do Itajaí - REAVI, v.09, nº 14, p. 115-126, ago. 2020.

ISSN: 2316-4190, DOI 10.5965/2316419009142020115 


\section{REAVI}

(CAMPOS; MONTEIRO; ORNELAS, 2000). Regarding the psychosocial factors that can influence the food consumption of elderly people who suffer from depression, which can be affected by weight loss (CAMPOS; MONTEIRO; ORNELAS, 2000).

Regarding the physical condition of the elderly, there is a loss of motor capacity. The process of buying food proves to be difficult because of the wide variety of products present in supermarkets, causing confusion, especially in the elderly at an older age (QUEVEDO-SILVA; LIMA-FILHO, D; FAGUNDES, 2018).

\section{MATERIALS AND METHODS}

This research is a single quantitative-descriptive cross-sectional study (MALHOTRA, 2006). The universe was composed of elderly supermarket consumers, living in the urban area of Campo Grande-MS, of both sexes and belonging to all economic classes.

The sample selected was made up of 100 people and the sampling technique used was non-probabilistic for convenience, which depends on the personal judgment of the interviewer and not on the probability of choosing sample elements, according to Malhotra (2006). Due to the promotions carried out by supermarkets, the survey was applied on different days of the week. The approach to the interview took place shortly after the shopping experience and the survey was conducted in three different supermarkets.

To assess the satisfaction of elderly consumers in relation to supermarkets, the questionnaire addressed: a) the attributes of supermarkets based on the research of Pei e Yin (2011) [Chart 1], measured using a Likert scale from 1 [Very dissatisfied] to 5 [Very satisfied]; and b) socio-demographic variables, including sex, housing and income.

Chart 1 - Variables used in the research
\begin{tabular}{|l|}
\hline VARIABLES \\
\hline 1. Proper lighting \\
\hline 2. Parking with exclusive spaces for the elderly \\
\hline 3. Number of preferred cash registers for the elderly \\
\hline 4. Modernity and efficiency of equipment \\
\hline 5. Cleaning \\
\hline 6. Overall assessment of the supermarket \\
\hline 7. Signs with good visibility \\
\hline 8. Signage inside the supermarket and parking \\
\hline 9. Organization of products on gondolas \\
\hline 10. Ease of finding products \\
\hline 11. Indoor supermarket space \\
\hline 12. Quality of products for sale \\
\hline 13. Variety of products available \\
\hline 14. Number of offers and promotions \\
\hline 15. Specific products for the elderly \\
\hline 16. Delivery \\
\hline 17. Customer service \\
\hline 18. Employees trained to care for the elderly \\
\hline 19. Friendliness of staff \\
\hline
\end{tabular}

Source: Elaborated by the authors

Revista Eletrônica do Alto Vale do Itajaí - REAVI, v.09, nº 14, p. 115-126, ago. 2020. ISSN: 2316-4190, DOI 10.5965/2316419009142020115 
Data analysis was divided into two stages, being performed with the aid of the Minitab software (MINITAB, 2010). In the first step, in order to better identify the most relevant variables for the satisfaction of elderly consumers, a factor analysis was performed using the variables present in Chart 1 . This procedure was necessary to reduce the data, facilitating its understanding, as instructed by Hair et al. (2009), also allowing to verify how many and which dimensions of supermarkets are perceived by consumers.

To determine the number of factors, the Latent Root criteria were used together with the Scree test. To distribute the factor loads among the factors, the Varimax orthogonal rotation technique was used (HAIR et al., 2009). Then, multiple scales were created using the arithmetic mean of the variables of each factor and validated with Cronbach's Alpha, since all factors presented values above 0.70, as recommended by Hair et al. (2009).

In the second stage, an agglomerative cluster analysis was performed (HAIR et al., 2009). The cluster analysis aims to form segments that present internal homogeneity [intra-cluster] and external heterogeneity [inter-cluster]. The analysis begins with one cluster for each consumer - in this case 100 clusters - and then, to minimize the internal variation of the clusters formed, the closest ones are started to group together to form a single cluster (HAIR et al., 2009).

To select the ideal number of segments, the percentage variation of the agglomeration coefficients was observed, which precisely indicate the heterogeneity within the clusters, together with a graphical analysis of the results (HAIR et al., 2009). After selecting the number of segments, their identification was carried out by analyzing their characteristics.

\section{RESULTS}

One hundred elderly people (over 60 years old) were interviewed, 33\% were men and $67 \%$ women. Due to the high mortality of young men due to external causes, caused mainly by accidents and homicides, Brazilian women have greater longevity and participation in the population over 60 years old (TEIXEIRA et al. 2006).

According to the questionnaire applied, 93\% of women claimed to live with a family or relative, as well as $83 \%$ of men made the same statement. The percentage of respondents who are satisfied with the supermarket in which they shop is approximately $64 \%$ and $27 \%$ said they are completely satisfied.

Of the $64 \%$ of elderly people who answered the question regarding income, $71 \%$ were women and $29 \%$ men, the answer with the highest number of respondents for women was that $55 \%$ of them had a personal monthly income of up to 1 minimum wage, while for men, the answer with the highest score was that they received 2 to 5 minimum wages, corresponding to $74 \%$ of male respondents.

In order to analyze elderly consumers, a factor analysis was first performed in order to reduce the data, facilitating its understanding (Hair et al., 2009), and mainly to verify how many and which dimensions are perceived by the consumers studied. After the preliminary analysis, it was realized that, based on the criteria of the Latent Root together with the Scree test (HAIR et al., 2009), the number of factors should be six.

Thus, when examining the factor loads for each variable, it is possible to notice that there is a logical link between the variables of each factor, making it even possible to name them. 


\section{REAVI}

Thus, the four factors defined are: Organization [Factor 1], Employees [Factor 2], Products sold [Factor 3] and Facilities [Factor 4], as show in Table 1.

After that, multiple scales were created using the arithmetic mean of the variables for each factor and validated with Cronbach's Alpha, since all factors presented values above 0.70, as recommended by Hair et al. (2009).

Table 1: Factor loads.

\begin{tabular}{|c|c|c|c|c|}
\hline VARIÁVEIS & Factor 1 & Factor 2 & Factor 3 & Factor 4 \\
\hline 2. Parking with exclusive spaces for the elderly & 0,648 & & & \\
\hline 5. Cleaning & 0,738 & & & \\
\hline 9. Organization of products on gondolas & 0,649 & & & \\
\hline 10. Ease of finding products & 0,685 & & & \\
\hline 11. Indoor supermarket space & 0,588 & & & \\
\hline 17. Customer service & & 0,843 & & \\
\hline 18. Employees trained to care for the elderly & & 0,866 & & \\
\hline 19. Friendliness of staff & & 0,779 & & \\
\hline 12. Quality of products for sale & & & 0,799 & \\
\hline 14. Number of offers and promotions & & & 0,811 & \\
\hline 4. Modernity and efficiency of equipment & & & & $-0,566$ \\
\hline 7. Signs with good visibility & & & & $-0,533$ \\
\hline 8. Signage inside the supermarket and parking & & & & 0,673 \\
\hline 15. Specific products for the elderly & & & & $-0,559$ \\
\hline Mean & 3,9 & 3,9 & 4,0 & 3,5 \\
\hline
\end{tabular}

Source: Research data

The Facilities [Factor 4] was considered the factor that causes the least satisfaction for the interviewees, receiving an average score of 3.5. Factors 1 to 3 had statistically equal scores, demonstrating that for respondents, the degree of satisfaction is the same for these three factors. This finding is contrary to what Richers and Lima (1991) mention regarding segmentation as a subdivision of the global market into potential portions, with similar needs and desires in order to formulate marketing strategies. Strategies that are somewhat flawed, since respondents encounter difficulties in supermarkets that hinder the purchase process. However, it corroborates the statements of Blackwell, Miniard and Engel (2002), since the elderly consumers form a market segment by having similar needs and behaviors.

It is worth mentioning that the four factors defined for this analysis are in the retail mix, as they are controllable factors that retailers have to articulate their strategies and conquer consumer preference according to Parente (2000).

According to Bone (1991), segmentation based on chronological age may not be an instrument of effective representation, since psychological age, the one we feel is more related to behavior than chronological age. Although chronological age segmentation is not an appropriate method for developing market strategies, it is still the most used in Brazilian publications.

Thus, to verify the possible existence of different segments among the respondents, an agglomerative hierarchical analysis of clusters was carried out, as instructed by Hair et al. (2009), using the variables related to the respondents' satisfaction. The agglomeration coefficients presents in table 2, which indicate the degree of homogeneity of the formed segments, together with the graphical analysis of the results, present in figure 1, identified three segments. After selecting the number of segments, it is necessary to characterize them. For that, the characteristics of each segment were analyzed using the Chi-square test.

Revista Eletrônica do Alto Vale do Itajaí - REAVI, v.09, nº 14, p. 115-126, ago. 2020.

ISSN: 2316-4190, DOI 10.5965/2316419009142020115 


\section{REAVI}

Table 2: Factor loads.

\begin{tabular}{c|c|c}
\hline CLUSTERS & AGGLOMERATION COEFFICIENT & PERCENTAGE VARIATION \\
\hline 10 & 15,716 & $6 \%$ \\
9 & 16,632 & $3 \%$ \\
8 & 17,191 & $15 \%$ \\
7 & 19,782 & $5 \%$ \\
6 & 20,824 & $34 \%$ \\
5 & 27,815 & $13 \%$ \\
4 & 31,568 & $32 \%$ \\
3 & 41,639 & $194 \%$ \\
2 & 122,543 & $11 \%$ \\
1 & 135,524 & \\
\hline
\end{tabular}

Source: Research data

Figure 1 - Dendrogram

Similarity

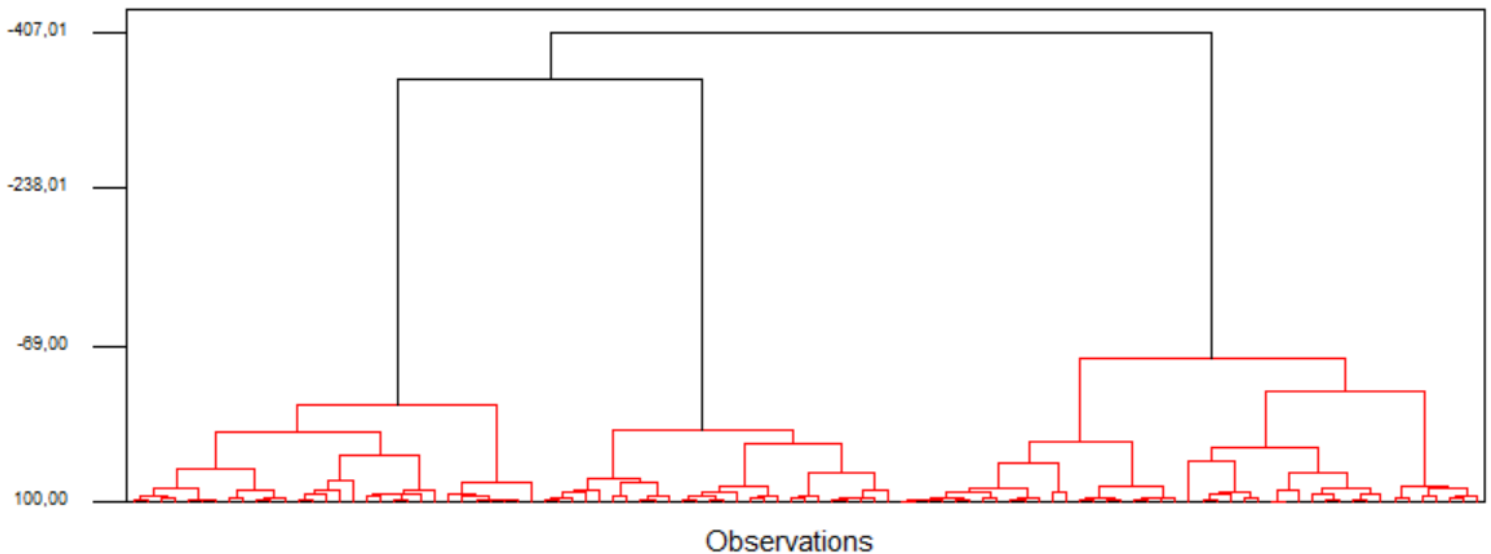

Source: Research data

Segment 1 comprises $26 \%$ of the sample. In this group, the percentage of women was around $73 \%$, the largest share receiving a minimum wage. This group proved to be more satisfied than the others in factors 1 to 4 . It seems that this group feels attended.

Segment 2 is made up of $44 \%$ of respondents. In this cluster, the number of women is equal to that of men, respectively $56 \%$ and $44 \%$ and the average income is 1 to 4 wages. This group had a satisfaction similar to that of the others, with emphasis on the factor General evaluation, in which it was the least satisfied. Demonstrating that retail is not yet segmenting the market according to Wedel and Kamakura (2000), that is, with the purpose of adjusting products or services to consumer needs.

Segment 3 is made up of $30 \%$ of respondents. In this segment, $76 \%$ of respondents are women and the largest share receives 2 to 4 minimum wages. This group is the most dissatisfied with factors 1 and 2, but the most satisfied in factor 4 .

These three segments corroborate the statements of Kotler (1998) regarding the segmentation variables that can be used alone or in combination.

Revista Eletrônica do Alto Vale do Itajaí - REAVI, v.09, nº 14, p. 115-126, ago. 2020.

ISSN: 2316-4190, DOI 10.5965/2316419009142020115 


\section{REAVI}

\section{FINAL CONSIDERATIONS}

The main purpose of the present study was to analyze whether the infrastructure, services and products offered by supermarkets in Campo Grande (MS) satisfy the expectations of elderly consumers. The results shows the profile of the elderly consumers, identifying three market segments, and demonstrate that the elderly consumers surveyed at the time of purchase in supermarkets are not completely satisfied with supermarket infrastructure [Factor 4] but they are relatively satisfied with services [Factor 2] and products [ Factor 3] offered in supermarkets, responding to the objectives of this research.

When considering different segments among the respondents, it is noted that the challenges of retailers, in order to efficiently and effectively serve the elderly market, it is necessary to develop a strategic management based on the existence of segments within that segment, that is, they should not use the needs of elderly consumers based solely on chronological age, but on another range of characteristics such as sex and socioeconomic level.

Therefore, it is the time for retailers to reorganize their strategies to conquer this market, through actions that consider various items, among them the knowledge of this segment, the expectations of these customers, the adequacy regarding more specialized service, being thus sensitive to new changes. According to Kottler and Keller (2006), it is important for companies to know consumer behavior and thus serve customers effectively.

The contribution of this study resides in the importance of the discussion around the expectations and needs of the consumer of the third age for the managers and researchers of the area of marketing to outline strategies that attend these consumers that more and more stand out in the Brazilian society. Because, the aging population will cause significant impacts for several sectors since this segment of the population has its own needs and expectations.

Some limits are pointed out: the subjectivity of the answers provided by the interviewees and in relation to the sample size and the instrument for data collection. As a suggestion for future research, it is indicated to advance in the expansion of the sample not only in quantity but also in other regions and, still, a longitudinal study in which it can make comparison between periods with the purpose of ascertaining the influences of these consumers in retail.

\section{REFERENCES}

AHANI, A.; NILASHI, M.; IBRAHIM, O.; SANZOGNI, L.; WEAVEN, S. Market segmentation and travel choice prediction in Spa hotels through TripAdvisor's online reviews. International Journal of Hospitality Management, v. 80, p. 52-77, 2019.

ANDRÉ, B.; CANHÃO, H.; ESPNES, G.A.; RODRIGUES, A.M.F.; GREGORIO, M.J.; NGUYEN, C.; SOUSA, R.; GRØNNING, K. Is there an association between food patterns and life satisfaction among Norway's inhabitants ages 65 years and older?. Appetite, v. 110, n. 1, p. 108-115, 2017.

BISSIOLI, P. Idoso: Versão Consumidor. Retrieved from: 〈http://www.itu.com.br >. In: 04 march. 2020.

BLACKWELL, R.D.; MINIARD, P.W.; ENGEL, J.F. Comportamento do consumidor.

Revista Eletrônica do Alto Vale do Itajaí - REAVI, v.09, nº 14, p. 115-126, ago. 2020. ISSN: 2316-4190, DOI 10.5965/2316419009142020115 
São Paulo: Thomson Learning, 2002.

BONE, P. F. Identifying mature segments. The Journal of Services Marketing, v.5 n. 1, p.47-60, 1991.

CABRINI, G. Formatos. SuperHiper, ano 40, n. RO 02/2014 p. 4-16, 2014.

CAMPOS, M. T. F. S.; MONTEIRO, J. B. R.; ORNELAS, A. P. R .C. Fatores que afetam o consumo alimentar e a nutrição do idoso. Ver. Nutr., Campinas, v. 13, n. 3, p. 157-165, set./dez., 2000.

CCRRCA - Coca Cola Retailing Council Asia. Food Retail Formats in Asia: understanding format success, 2007. Retrieved from:

<http://globalscorecard.gs1.org/gsclive/download/Food_Retail_Formats_in_Asia_Understanding _Format_Success-Study.pdf > In: 13 jan 2020.

DEBERT, G.G. A reinvenção da velhice. São Paulo: EDUSP, 1999.

EDWARDS, J. S. A.; GUSTAFSSON, I. B. The room and atmosphere as aspects of the meal: a review. Journal of Foodservice, v. 19, n.1, p.22-34, feb, 2008.

ESTATUTO DO IDOSO: lei $\mathbf{n}^{\circ} \mathbf{1 0 . 7 4 1}$, de $\mathbf{1}^{\mathbf{0}}$ de outubro de 2003. Retrieved from: <http://www.planalto.gov.br/ccivil_03/leis/2003/110.741.htm>. In: 25 april 2019.

FURUTA, E. C.; BARRIZZELLI, N. Razões de escolha de supermercado de vizinhança como local de compra. 2002. Retrieved from:

<http://www.ead.fea.usp.br/TCC/trabalhos/Artigo_ErikaFuruta.pdf >. In: 19 de outubro de 2019.

HAIR, J. F.; BLACK, W.C.; BABIN, B.J.; ANDERSON, R.E.; TATHAM, R.L. Análise multivariada de dados. 6. ed. Porto Alegre: Bookman, 2009.

IBGE - Instituto Brasileiro de Geografia e Estatística. Retrieved from:

http://www.ibge.gov.br/home/estatistica/populacao/condicaodevida/indicadoresminimos/sintesei ndicsociais2010/SIS_2010.pdf

KANUK, L.L.; SCHIFFMAN, L.G. Comportamento do consumidor. 6.ed. Rio de Janeiro: LCT, 2000.

KOTLER, P. Administração de marketing: análise, planejamento, implementação e controle. São Paulo: Atlas, 1998.

KOTLER, P.; KELLER, K. L. Administração de Marketing: A Bíblia do Marketing. 12. ed. São Paulo: Pearson Prentice Hall, 2006. 


\section{REAVI}

MALHOTRA, N. K. Pesquisa de marketing: uma orientação aplicada. 4. ed. Porto Alegre: Bookman, 2006.

MINITAB. Minitab statistical software user`s guide 2: data analysis and quality tools. State College, PA, USA: Minitab Release 16, Minitab Inc, 2010.

MOWEN, J. C.; MINOR, M. S. Comportamento do consumidor. São Paulo: Prentice Hall, 2003.

PARENTE, J. Varejo no Brasil: gestão e estratégia. São Paulo: Atlas, 2000.

PEI, E.; YIN, Y. An ethnographic approach towards understanding the food shopping experience of the elderly consumer. In: Tsinghua-DMI International Design Management Symposium, 2011, Hong Kong. Proceedings... Hong Kong: HK, 2011. p. 01- 11.

QUEVEDO-SILVA, F.; LIMA-FILHO, D.; FAGUNDES, M. Dimensions of food choice process of older consumers in Brazil, British Food Journal, v. 120, n. 5, p. 984-998, 2018.

RICHERS, R.; LIMA, C. P. Segmentação. São Paulo: Nobel, 1991.

SMITH, W. R. Product differentiation and marketing segmentation as alternative marketing strategies. American Marketing Association. Journal of Marketing, vol. 21, pp. 3-8, julho, 1956.

SPROESSER, R. L.; LIMA-FILHO, D. O. Varejo de alimentos: estratégia e marketing. in: BATALHA, Mário O. Gestão agroindustrial; 3. ed. São Paulo: Atlas, 2007.

WEDEL, M; KAMAKURA, W. A. Market segmentation: conceptual and methodological foundations. $2^{\text {nd }}$. Boston, Kluwer Academic, 2000. Xxxii, 382p. 